\title{
ISO-ANTIBODY FORMATION AGAINST RABBIT SPERMATOZOA AND ITS EFFECT ON FERTILITY
}

\author{
E. B. BELL* \\ Institute of Animal Genetics, Edinburgh, Scotland
}

(Received 30th May 1969)

Several investigators have questioned whether rabbit spermatozoa are isoantigenic (Edwards, 1960; Weil, 1960; Beck, Edwards \& Young, 1962) and only recently (by injecting rabbit spermatozoa emulsified in Freund's complete adjuvant) has immunological control of fertility been adequately demonstrated (Menge, 1968). In the preliminary experiment to be reported, the injection of homologous spermatozoa in sodium alginate evoked high levels of iso-antibody against rabbit spermatozoa and suppressed fertility. The infertility resulted from a failure of eggs to become fertilized.

Fourteen rabbits (nine known fertile, five virgin), ranging in age from 9 to 20 months, were randomly assigned to experimental and control groups. All animals were injected weekly for 10 weeks before the first insemination and then again once before each succeeding insemination. On each occasion, experimental animals received $0.25 \mathrm{ml}$ of sperm-alginate suspension $\left(5 \times 10^{7}\right.$ epididymal spermatozoa/ml) into each of the four footpads, and $0.5 \mathrm{ml}$ subcutaneously into the nuchal region. In addition, approximately $1 \mathrm{ml}$ was introduced (with the aid of a vaginal speculum) intravaginally on an absorbent cotton tampon. Control rabbits received equivalent footpad, nuchal and intravaginal administrations of sterile saline. Spermatozoa for injection were obtained by reverse flushing of the vas deferens and cauda of the epididymis with the adjuvant sodium alginate containing $0.67 \%$ calcium gluconate (Medical Alginates Ltd).

Ten or 11 days after the last injection, rabbits were mated with a known fertile buck (on the first occasion) or (on subsequent occasions) artificially inseminated $1 \mathrm{hr}$ after the intravenous injection of $50 \mathrm{i}$.u. of human chorionic gonadotrophin. In each test, all fourteen rabbits were inseminated with $5 \times 10^{7}$ spermatozoa from a single pool within $2 \mathrm{hr}$ of collection.

At term, litter size was recorded and offspring removed immediately. Periods of 8,1 and 16 weeks elapsed respectively between parturition and the next injection of antigen. Haemorrhagic protrusions on the ovary were taken as evidence of ovulation. Eggs, flushed from the Fallopian tubes 24 to $36 \mathrm{hr}$ after insemination, were considered to have been fertilized if one or more normal cleavages had occurred.

Blood samples were collected by cardiac puncture 10 to 13 days after the last

* Present address: Department of Experimental Immunobiology, The Wellcome Research Laboratories, Langley Court, Beckenham, Kent. 
injection preceding each insemination. Serum antibody against rabbit spermatozoa was measured by the passive haemagglutination test (including controls for specificity) as described previously for mouse spermatozoa (Bell, 1969a). Thus, the supernatant fraction of three-times washed rabbit spermatozoa $\left(10^{8}\right.$ spermatozoa/ml pooled ejaculates), homogenized twice in a Ribi cell fractionator at 20,000 and $30,000 \mathrm{lb} / \mathrm{sq}$. inch, was used to sensitize tannic-acid-treated sheep erythrocytes. The titres found are given in Table 1.

TABle 1

REGIPROGAL SERUM TITRES, FERTILIZATION RATES AND TOTAL NUMBERS OF OFFSPRING FROM RABBITS IMMUNIZED WITH RABBIT SPERMATOZOA

\begin{tabular}{|c|c|c|c|c|c|c|}
\hline Rabbit & First & $\begin{array}{l}\text { Serum } \\
\text { Second }\end{array}$ & $\begin{array}{l}\text { lection } \\
\text { Third }\end{array}$ & Fourth & $\begin{array}{c}\text { Eggs } \\
(\text { fertile|total })\end{array}$ & $\begin{array}{c}\text { Total } \\
\text { offspring }\end{array}$ \\
\hline $\begin{array}{r}8 \\
9 \\
10 \\
11 \\
12 \\
13 \\
14\end{array}$ & $\begin{array}{l}\text { Neg } \\
4608 \\
\text { Neg } \\
\text { Neg } \\
1152 \\
4608 \\
9216\end{array}$ & $\begin{array}{l}\text { Neg } \\
4608 \\
\text { Neg } \\
\text { Neg } \\
2304 \\
4608 \\
9216\end{array}$ & $\begin{array}{r}\text { Neg } \\
4608 \\
\text { Neg } \\
\text { Neg } \\
2304 \\
9216 \\
36800\end{array}$ & $\begin{array}{c}\text { Neg } \\
4608 \\
\text { Neg } \\
\text { Neg } \\
2304 \\
36800 \\
147200\end{array}$ & $\begin{array}{c}?^{*} \\
? \\
2 / 3+ \\
? \\
0 / 9 \\
0 / 7 \\
0 / 8\end{array}$ & $\begin{array}{r}7 \\
0 \\
0 \\
17 \\
0 \\
0 \\
0\end{array}$ \\
\hline
\end{tabular}

* ? = No eggs were recovered due to abscesses of the ovarian bursa resulting from the ovarian examination of the previous pregnancy.

$\dagger$ Results of only one ovary. The opposite oviduct was blocked by a spherical calculus and contained five unfertilized eggs.

The results of four separate inseminations are summarized in Table 2. The high rate of infertility encountered in the control animals when mated with fertile bucks (first insemination period) obscured any effect of treatment on

TABLE 2

SUMMARY OF FERTILITY OF RABBITS INJECTED WITH RABBIT SPERMATOZOA (IMMUNIZED) OR SALINE (CONTROL) AFTER FOUR SEPARATE INSEMINATIONS

\begin{tabular}{c|l|c|c|c|c|c}
\hline $\begin{array}{c}\text { Insemination } \\
\text { period }\end{array}$ & \multicolumn{1}{c|}{ Group } & $\begin{array}{c}\text { Non- } \\
\text { pregnant }\end{array}$ & Pregnant & $\begin{array}{c}\text { Mean } \\
\text { litter size }\end{array}$ & $\begin{array}{c}\text { Mean no. } \\
\text { ovulation points }\end{array}$ & $\begin{array}{c}\text { Eggs } \\
\text { (fertile/total) }\end{array}$ \\
\cline { 1 - 5 } First & Immunized & 5 & 2 & 0.57 & & \\
& Control & 4 & 3 & $2 \cdot 29$ & & \\
Second & Immunized & 5 & 2 & 1.71 & & \\
& Control & 1 & 6 & 5.43 & & \\
Third & Immunized & 5 & 2 & $1 \cdot 14$ & 8.29 & \\
& Control & 2 & 3 & $3 \cdot 20$ & $9 \cdot 29$ & $22 / 22 *$ \\
& Immunized & & & & 7.57 & $2 / 27$ \\
& Control & & & & 9.00 & $52 / 53 \dagger$ \\
\hline
\end{tabular}

* Eggs (blastocyst stage) recovered from two rabbits which died during the surgical procedure for recording ovulation points.

$\dagger$ Includes two multiparous rabbits added before the final injections to replace the two animals lost in the previous insemination period.

pregnancy rate and prompted the use of artificial insemination thereafter. In the second insemination period, a comparison of pregnant versus non-pregnant animals showed a significant effect $(P=0.026$, Fisher, 1958) of sperm injection on fertility, allowing for the fact that the effect of treatment was expected in 
only one direction. If one tests only animals synthesizing specific antibody (Table 1) the observed pregnancy rates $(0 / 4$ in antibody producers, $6 / 7$ in controls) give a significance value of $P=0.008$.

Examination of the ovaries during the next pregnancy, 5 to 7 days after insemination, ruled out the possibility that inability to conceive was due to a failure to induce ovulation with HCG. Ovulation occurred in all animals.

After a final insemination, eggs were examined for evidence of fertilization. A total of seventy-five eggs was recovered from nine saline-injected rabbits (Table 2), 98.7\% of which were fertile. No eggs were obtained from three of the immunized animals (Table 1). From the remaining four, twenty-seven eggs were recovered, of which only two were fertile, showing that prevention of fertilization was responsible for the induced infertility.

Of the sperm-injected rabbits, only four produced detectable antibodies (Table 1). These four rabbits were apparently sterile during the entire experiment. Every one of the remaining animals (control and immunized) showed negative serum titres and at some stage in the experiment were fertile.

The induction of infertility observed could be accounted for by a failure of fertilization, implying a lethal effect on the spermatozoon itself, rather than, as has been postulated by Katsh (1957, 1959), an anaphylactic reaction of the uterus or by Menge (1967, 1969), an early death and reabsorption of embryos. Others have also observed an effect on rate of fertilization (McLaren, 1964; Edwards, 1964; Menge, 1968).

The notion that rabbit spermatozoa are not iso-antigenic (Edwards, 1960; Weil, 1960; Beck et al., 1962) arose from the failure of investigators to raise detectable antibody against epididymal spermatozoa, and from the finding that ejaculated spermatozoa possess irreversibly adherent seminal plasma antigens which account for apparent titres. In the present experiment, antibody against homologous epididymal spermatozoa was stimulated by injection of rabbit spermatozoa suspended in sodium alginate, an adjuvant not previously employed for sperm immunization. The high titres obtained suggest that isoantigenicity depends heavily on employing a suitable adjuvant, a sufficient injection schedule and an adequate immunological assay. Lack of iso-antigenicity is not a property, as such, of the species.

Sodium alginate may be more suitable than Freund's as an adjuvant in studies on induced infertility, because Freund's can cause pathological changes in many organs (Ram, Glenner \& DeLellis, 1968; Plank, Hunt \& Cohen, 1967; Boss, 1965) and affect the oestrous cycle (Battisto, Pinto \& Joseph, 1967).

In addition to systemic injection, the rabbits received intra-vaginal spermalginate-soaked tampons. Although the rabbit vagina has been shown to be capable of de novo antibody production (Bell \& Wolf, 1967), no antibody to spermatozoa was detected in vitro in the present experiment after culturing the antigen-exposed vaginae of the immunized females (Bell, 1969b), so it is unlikely that antibodies produced locally in the vagina contributed to the effect on fertility.

I would like to thank Dr Anne McLaren for criticism of the manuscript and Dr David Woolley for valuable assistance. This investigation was supported by 
a Public Health Service Fellowship (No. 5-F2-HD-30, 823-03) from the National Institute of Child Health and Human Development.

\section{REFERENCES}

Battisto, J. R., Pinto, M. \& Joseph, S. (1967) Disturbance of oestrous cycles in rats following administration of Freund's complete adjuvant. J. Reprod. Fert. 14, 147.

Beck, J. S., EDwards, R. G. \& Young, M. R. (1962) Immune fluorescence technique and the isoantigenicity of mammalian spermatozoa. 7. Reprod. Fert. 4, 103.

BeLl, E. B. (1969a) Immunological control of fertility in the mouse: a comparison of systemic and intravaginal immunization. F. Reprod. Fert. 18, 183.

BELL, E. B. (1969b) Immunological aspects of the reproductive system in laboratory animals. Ph.D. thesis, University of Edinburgh.

Bell, E. B. \& Wolf, B. (1967) Antibody synthesis in vitro by the rabbit vagina against diphtheria toxoid. Nature, Lond. 214, 423.

Boss, J. H. (1965) Autoimmune renal disease. The production of autoimmune renal disease in the rat by homoimmunization with organ-heterologous material. Medna Pharmacol. exp. 12, 345.

EDwards, R. G. (1960) Antigenicity of rabbit semen, bull semen and egg yolk after intravaginal or intramuscular injection of female rabbits. 7 . Reprod. Fert. 1, 385.

EDWARDs, R. G. (1964) Immunological control of fertility in female mice. Nature, Lond. $203,50$.

Fisher, R. A. (1958) Statistical methods for research workers, 13th edn, p. 96. Oliver \& Boyd, Edinburgh.

KATsH, S. (1957) In vitro demonstration of uterine anaphylaxis in guinea pigs sensitized with homologous testis or sperm. Nature, Lond. 180, 1047.

Katsh, S. (1959) Infertility in female guinea pigs induced by injection of homologous sperm. Am. $\mathcal{F}$. Obstet. Gynec. 78, 276.

McLaren, A. (1964) Immunological control of fertility in female mice. Nature, Lond, $201,582$.

Menge, A. C. (1967) Induced infertility in cattle by iso-immunization with semen and testis. 7. Reprod. Fert. 13, 445.

Menge, A. C. (1968) Fertilisation, embryo and fetal survival rates in rabbits isoimmunized with semen, testis, and conceptus. Proc. Soc. exp. Biol. Med. 127, 1271.

Menge, A. C. (1969) Early embryo mortality in heifers isoimmunized with semen and conceptus. 7. Reprod. Fert. 18, 67.

Plank, S. J., Hunt, R. D. \& Cohen, A. S. (1967) Amyloidosis in guinea-pigs immunized with sperm and adjuvant. Nature, Lond. 214, 1368.

Ram, J. S., Glenner, G. G. \& DeLellis, R. A. (1968) Amyloid. I. Use of Freund's adjuvant in experimental amyloidosis. Proc. Soc. exp. Biol. Med. 127, 854.

WEIL, A. J. (1960) Immunological differentiation of epididymal and seminal spermatozoa of the rabbit. Science, $\mathcal{N} . \Upsilon .131,1040$. 